\author{
Roger Chabot \\ The University of Western Ontario, London, Ontario, Canada
}

\title{
LIFE IS SUFFERING: THROWNNESS, DUHKHA, GAPS, AND THE ORIGIN OF EXISTENTIAL-SPIRITUAL NEEDS FOR INFORMATION
}

\begin{abstract}
:
LIS scholars have spent considerable time investigating the incipient stages of information seeking: the so-called "information need" as well as a host of other motivators. A study of twenty New Kadampa Buddhists, whose experiences were collected through semi-structured interviews, sought to explore their spiritual information practices and their motivations for engaging in such behaviour. An analysis of these interviews suggests that Martin Heidegger's concept of thrownness can be paralleled with Buddhism's First Noble Truth and Dervin's gap metaphor, all which identify existential-level faults as inherent to the human condition. This paper offers that it is these closely-related problematic elements of human existence that are the origin of spiritual and existential motivations for engaging in spiritual information practices.
\end{abstract}

\section{Introduction}

A need for information can be understood as "the motivation people think and feel to seek information" (Cole, 2012, p. 3). LIS scholars have spent considerable time unravelling the complex web of needs, wants, desires, and states that have been used to describe the incipient stages of information seeking. In a similar manner, psychology of religion scholars sought to explain the origins of the motivations behind individuals' pursuit of religious or spiritual paths, concluding that they satisfy one or more 'fundamental' or 'basic' human needs or motives (Kirkpatrick, 2013) and that they are a manner of "facilitat[ing] dealing with fundamental existential issues" (Oman, 2013, p. 36). Spiritual teachings, understood as information, play a large role in the everyday practice of spiritual paths and thus could be similarly motivated by these concerns.

\section{Method}

To investigate this, twenty self-identified Buddhist practitioners from the New Kadampa Tradition of Buddhism participated in semi-structured interviews between May and August 2016. Participants were recruited in-person at New Kadampa events in Canada as well as through unofficial New Kadampa Facebook groups. Thirteen participants were female, seven were male. The median age of these practitioners was 53 years, and have spent an average of eight years involved in Buddhism. Sixteen interviews were conducted by Skype, and four were conducted in person. All were audio recorded and 
transcribed. A thematic analysis of the interviews followed, according to suggestions from Corbin \& Strauss (2008).

The discussion of the results of the interviews, of which an excerpt is presented here, was performed based on the triangulation of three avenues of thought: (1) Martin Heidegger's ontological hermeneutics, (2) Buddhist psychology, and (3) Dervin's Sense-making methodology. This discussion offers the idea that Heidegger's concept of thrownness can be paralleled with Buddhism's First Noble Truth and Dervin's gap metaphor, which all identify an existential-level suffering or fault as inherent to the human condition and that it is this suffering that is a motivator for seeking spiritual information and engaging in spiritual information practices.

\section{Thrownness, Duhkha, and Gaps}

As part of Heidegger's analysis of being, in which he attempts to describe human beings' existential constitution, he reveals an anxious and struggling human being (Dasein) who finds himself being in a world which is troublesome. That is, Dasein is always finding itself thrown into the world. Wheeler (2011) explains that thrownness defines the characteristics of "Dasein having to deal with having-beenthrown into the world" (s. 2.2.7., para. 2). In other words, it is without choice that Dasein finds itself constantly in a world, and is consequently responsible for its own being, and for being mattering to it. Withy (2014) supplies "That human life is such a business is the naked fact that we are and have to $b e$ " (p. 74). The effect of such thrownness is that "we are 'subject to' life...it 'burdens' us in the sense that we cannot extricate ourselves from caring about it" (Blattner, 2006, p. 78). Heidegger is suggesting that at a fundamental level being-in-the-world is a problem for humans.

The Buddhist explanation of human beings' existential situation, as encapsulated in the First Noble Truth, closely resembles Heidegger's explanation of Dasein as a being thrown into the world, as it too asserts that everyday human existence to be problematic. In the Buddhist explanation, life is pervaded by duhkha. Duhkha is usually translated from Sanskrit as 'suffering', 'unsatisfactoriness', 'frustration', 'unhappiness', 'anguish', 'ill', or 'dis-ease' (Bowker, 2003). Duhkha is pervasive and is a result of human existence having a conditioned existence. That is, human existence is the result of a series of causes and effects and thus is constantly subject to decay and destruction. Consequently, every aspect of human beings' everyday life will eventually end in tragedy: youth will develop into old age, wellness and health into sickness, and being born means that one day death will come. Ultimately, human beings suffer human sufferings because they have a human body and mind, they are trapped in a human situation. Garfield (2015) writes, "Siddharta Gautama's genius was not simply to see that we suffer, or that many of us are unhappy. That has been noted many times by philosophers in many traditions. His genius was instead to see that dukkha is the fundamental structure of our lives...to be human is to live in dukkha" (p. 9). Duhkha then, is similar to Heidegger's thrownness. They both describe a human being forced to struggle with the experience of being alive.

Here, Dervin's gaps also find a striking parallel with thrownness and duhkha. First, Dervin (2003/1991) asserts that "the gap idea is a fundamental assumption...about the nature of the human condition" (p. 63). Her language here points to gaps being connected with human experience at a profound level. Gaps are disclosed to human individuals when the "mover sees movement as somehow deterred or fettered" (Dervin, 2003/1980, p. 44) through time and space. In other words, gaps occur when a human encounters discontinuity--a problem, a new situation, a decision--any time where sense has run out and new sense must be made. The gappiness of the human condition, while existential, is also pervasive. Dervin and Huesca (2003) write that there is an "inherent discontinuity of existence--the idea that reality is itself inherently gap-filled with gaps between entities, between times, and between spaces" (p. 317). Similar to thrownness and duhkha, Dervin takes as a metaphysical basis for her Sense-making methodology an 
imperfect reality--one that is obstacle-filled. Furthermore, like thrownness and duhkha, the human individual, the sense-maker, has no choice but to navigate the gappiness of the human condition. As a result of this comparison, we can understand existential-level problems like thrownness and duhkha in the study of information behavior as gaps.

\section{Evidence and Discussion}

It is evident from the statements of the participants interviewed that they have encountered gaps that are consistent with thrownness or duhkha and that were the catalyst to seeking spiritual information as an attempt to resolve or move away from these problematic existential states. Notably, these gaps presented by the interview participants fall along a continuum of articulatedness (that is, the degree in which the gap was articulated as a question). This articulatedness is important because it signals what type of gapbridging or outcome participants are searching for. Statements from Kyle and Nathan offer the most articulated questions:

[T] he pressing question for me is that ordinary life appears quite meaningless and so it appears especially meaningless within the context of birth, old age, sickness and death. So, for me, engaging with the Dharma [Buddha's teachings] is about trying to find a way to respond appropriately to that existential truth, to not shirk that question, to actually find a meaning, find a way of living that is meaningful in light of those. (Kyle)

There is a main question that lead me to the spiritual path. It was about death. What is death? Why do we die? What happens after death? To me, Dharma is a great way to prepare myself for death and to be conscious about what death is... (Nathan)

Kyle's and Nathan's questions recognize the specific problematic aspects of existence and interrogate them. They are attempting to make sense of their human existence. They see themselves stopped at the gaps of sickness at death and are seeking for answers so that they can bridge these particular existential problems.

Next, Nathan and Julia offer not-as-articulated gaps. They have not quite identified the characteristics of their thrownness or duhkha, yet they still aware of the presence of a gap--that there is stopping of movement forward particularly when there is suffering. They reported:

The other one was a kind of dissatisfaction with everything that arrived in my life. I've been trying to find, to figure out, new sources of satisfaction for myself, sources that came from inside rather than from outside. (Nathan)

When I'm suffering. When I have a problem that I need to solve, or if I'm feeling out of sorts, or down. (Julia)

For both Nathan and Julia, each time they experienced gross suffering or dissatisfaction there was a discontinuity of movement forward through time and space. Eventually, their suffering was motivation to bridge the gap of suffering in a new way: the seeking of Buddhist spiritual information. Participants' noted gaps suggest that a true bridging of these existential gaps is, in the words of James (1958/1902) "a life not correlated with death, a health not liable to illness, a kind of good that will not perish" (p. 121), which suggests that the best answer to thrownness, to duhkha, to the gappiness of the human condition, is to no longer be human, and perhaps to become divine. In the Buddhist context, this is achieved by engaging in the spiritual information practices that comprise the Buddhist path. 


\section{Conclusion}

Scholars have variously characterized information needs as deriving from uncertainty, or as a means of problem-solving, decision-making, or sense-making, suggesting that the 'information need' as a discrete phenomena, does not truly exist. In a similar vein, the essence of these existential motivators can be described as avoiding the uncomfortableness of being in one state and wishing to move to another. In many ways, the everyday explanations for why humans seek information can be reduced to a desire to avoid suffering--regardless of whatever 'level' this suffering originates. While this study does not lend itself to generalization, this paper invites further exploration of this proposition. It also advances the investigation of the "higher things in life" in LIS (Kari \& Hartel, 2007) such as spirituality which is an important aspect of individuals' everyday life.

\section{Reference List:}

Blattner, W. (2006), Heidegger’s ‘Being and Time’: A reader's guide. New York, NY: Continuum.

Bowker, J. (2003). Duhkha. In The Concise Oxford Dictionary of World Religions. Oxford, United Kingdom: Oxford University Press.

Cole, C. (2012). Information need: A theory connecting information search to knowledge formation. Medford, NJ: Information Today.

Corbin, J., \& Strauss, A. (2008). Basics of qualitative research, third edition. Thousand Oaks, CA: Sage.

Dervin, B. (2003/1980). Communication gaps and inequities: Moving toward a reconceptualization. In B. Dervin, L. Foreman-Wernet, \& E. Lauterbach (Eds.), The Sense-making Methodology Reader: Selected Writings of Brenda Dervin (pp. 309-324). Creskill, NJ: Hampton Press.

Dervin, B. (2003/1991). Comparative theory reconceptualized: From entities and states to processes and dynamics. In B. Dervin, L. Foreman-Wernet, \& E. Lauterbach (Eds.), The Sensemaking Methodology Reader: Selected Writings of Brenda Dervin (pp. 309-324). Creskill, NJ: Hampton Press.

Dervin, B. \& Huesca, R. (2003). Practicing journalism communicatively: Moving from journalism practiced as ideology to journalism practiced as theorized practice. In Dervin, B., ForemanWernet, L., \& Lauterbach, E. (Eds.), The Sense-making Methodology Reader: Selected Writings of Brenda Dervin (pp. 309-324). Creskill, NJ: Hampton Press.

Garfield, J. L. (2015). Engaging Buddhism: Why it matters to philosophy. New York, NY: Oxford University Press.

James, W. (1958/1902). The varieties of religious experience. New York, NY: American Library.

Kari, J., \& Hartel, J. (2007). Information and higher things in life: Addressing the pleasurable and the profound in information science. Journal of the American Society of Information Science and Technology, 58(8), 1131-1147. 
Kirkpatrick, L. A. (2013). Evolutionary psychology as a foundation for the psychology of religion. In Paloutzian, R. F. \& Park, C. L., Handbook of the Psychology of Religion and Spirituality (pp. 118-137). New York, NY: The Guilford Press.

Oman, D. (2013). Defining religion and spirituality. In Paloutzian, R. F. \& Park, C. L. (Eds.), Handbook of the Psychology of Religion and Spirituality (pp. 23-47). New York, NY: The Guilford Press.

Wheeler, M. (2011). Martin Heidegger. Stanford Encyclopedia of Philosophy. Retrieved from: https://plato.stanford.edu/entries/heidegger/

Withy, K. (2014). Situation and limitation: Making sense of Heidegger on thrownness. European Journal of Philosophy, 22(1), 61-81. 